\title{
THE COCONUT INDUSTRY - SOLOMON ISLANDS
}

\author{
Brian G.C. Smith*
}

\section{SUMMARY}

The coconut plays a vital part in the culture and economy of Solomon Islands. Not only is it the main source of income to the majority of smallholders in the country it is also an important - food.

The Government has recently carried out a survey of the smallholder coconut sector which has produced valuable baseline data high government is basing a development programme.

Whilst a replanting programme is not envisaged farmers will encouraged through demonstrations based on research findings crease the output from the existing resource to improve rural and national incomes and to ensure a continuing supply of this food for the increasing population.

\section{INTRODUCTION}

Solomon Islands is an independent nation situated between to $177^{\circ}$ East and $40-12^{\circ}$ South of the equator. Solomon Islands are approximately $1,800 \mathrm{~km}$ north east of Australia and form a scattered archipelago stretching some 1,400 km from Bougainville in Papua New Guinea in the north west towards Vanuatu in the south east.

The country comprises of six major and numerous minor s with a total area of some 27,556 square kilometres. Guadalcanal, famous as a World War II battlefield is the largest on which is situated the capital, Honiara.

The large islands consist of a core of steep mountains of y dissected volcanic, metamorphic or sedimentary materials few areas of plain.

The smaller islands consist of atolls, raised atolls or volcanic islands with soils; of limited fertility except on those islands where the raised coral has been enriched with volcanic ash.

The majority of the population estimated in 1982 at 244,000 live on the main islands and is 93\% Melanesian with $90 \%$ of the population living in rural areas dependent an agriculture for food and cash income.

As in most if not all of the Pacific islands the coconut occupies a unique and important part in the life and culture of Solomon Islands. The coconut has been a staple food for centuries and has since 1895 been a source of income as an export crop. In addition as elsewhere in the world the coconut provides many of the necessities of everyday life.

A recent survey financed by the EEC and carried out by Agrar and Hydrotechnic G.B.H. (1985) has estimated the total area of coconuts in Solomon Islands to be 60,000 hectares with an estimated total number of palms of 9 million with a copra production in 1984 of 42,586 tonnes. $70 \%$ of production comes from the smallholder sector with the remainder from the commercial plantation and co-operative sector.

*Agricultural Adviser, Ministry of Agriculture and Lands, Government of Solomon Island. 
The majority of the commercial plantings are located within the central sector of Solomon Islands in Guadalcanal, Central and Isabel Provinces. Smallholdings are much more dispersed and occur throughout the provinces the bulk being concentrated in Western Province.

Plantings are generally along the littoral and rarely extend more than four or five kilometres inland.

As well as producing copra the coconut forms a basic staple food. It is estimated that the 40,000 rural households consume on average 5 nuts per household per day.

All coconut exports are of copra mostly to the European and Japanese markets. No oil mill exists in Solomon Islands although one soap factory does crush a small amount of copra for its own use.

Hansell \& Wall (1976) have shown that since the start of copra exports in 1895 the tonnage rose until the outbreak of World War 11. After the war production was at a very low level and took until 1963 to reach prewar levels. Ele (1982) states that in the 50's and 60's copra was the only major export accounting for between 80 and $90 \%$ of the total value of exports. Since then with the development of other commodities for export such as fish, timber and palm oil and kernels the value of copra exports has fallen to between $20 \%$ and $30 \%$ of the total and now stands at some $30-40000$ tonnes with 42,000 tonnes in 1985 .

Historically the type of coconut planted in Solomon Islands has been the Local Tall. In the last decade some interest has been shown in other types such as the Rennell, the Malayan Dwarf and the Dwarf Rennell hybrid but planting of these in the smallholder sector has been insignificant.

Traditionally smallholders obtained their seed from Missions commercial estates, their neighbours or mostly as germinated nuts from within their own plantations. There was little or no selection of planting material.

The age of palms is an important factor affecting the present and future productivity of the industry. The recent Coconut Survey has shown that in the smallholder sector half of the trees are assessed to be 15 years old or less. Ninety percent (90\%) are judged to be 40 years old $20 \%$ are, judged immature i.e. less than 6 years of age. The age structure is therefore skewed towards younger palms characterizing a dynamic smallholder industry with the capacity for expansion of output.

Levers Solomons LTD a joint venture between Unilever PLC and Solomon Islands Government, the major plantation company in the country is completing an extensive replanting programme using hybrids but elsewhere in the plantation sector as much as $70 \%$ of all palms are over their prime.

As well as the traditional smallholder and plantation sector a recent development in Solomon Islands has been the creation of Land Purchase Co-operatives. These cooperatives are a means of returning to the original traditional owners land that until recently was in the hands of expatriates and run as estates. However in returning this land to the original owners it is not the intention of the Government that they be split up into smallholdings but that they are run as co-operative estates with the management and economic advantages of a larger scale. The majority of these estates to date have been coconut plantations.

The coconut is a plant that is remarkably tolerant of adverse conditions. However there are a number of specific restricting factors present in Solomon Islands which in addition to poor levels of general management are restricting yields from reaching their potential. 
The majority of Solomon Islands soils are low in potash whereas coconuts have a high requirement for this nutrient. This is often exacerbated by planting coconuts on land that has previously been cropped for root crops such as sweet potato or taro, crops which also have a high potash requirement. Trials by the Solomon Islands Government (1982) have shown responses in many cases to the application of potash but to date with the exception of one or two estates little or no fertilizer is used.

Insect pests can cause problems during establishment and production. The major insect pests are :

$\begin{array}{ll}\text { Rhinocerous Beetle } & \text { Scapanes grossepunctatus } \\ \text { Premature nut fall insect } & \text { Amblypelta cocophaga } \\ \text { Coconut Spathe boner } & \text { Axiagastas cambellii } \\ \text { Coconut leaf beetle } & \text { Brontispa longissima }\end{array}$

Methods of both chemical and biological control of these pests is under investigation by the Agricultural Research Department of the Government. Perhaps the most serious pest is Amblypelta cocophaga which can cause complete loss of crop and this is particularly prevalent in Western Province. It is hoped to intensify work on this pest in 1987 with the recruitment of an entomologist to work full time on this problem.

Research on coconut problems in Solomon Islands began in the period between World War 1 and 11 with the employment of an entomologist. In the early 1960s a Joint Coconut Research Scheme was set up as a joint venture between the Government of Solomon Islands and Levers Pacific Plantations Pty Limited. In 1980 the Government purchased equity in and set tip a joint venture company with Unilever PLC named Levers Solomon Ltd. (LSL). At this time the Joint Coconut Research Scheme lapsed with the idea that LSL would continue research applicable to the plantation sector whilst government would carry out research for the smallholder. This arrangement is now under review.

During the past years a large amount of genetic material has been imported into Solomon Islands which has been. tested both as "varieties" and hybrids. As a result of this the presently recommended "variety" for replanting in the majority country is the Malayan Dwarf $x$ Rennell Tall hybrid. This hybrid is proving to be higher yielding, more precocious and needing less nuts to a tonne of copra than the traditionally grown tall varieties. Exceptions to this are in Temotu Province in the east where a recommendation is still under investigation and on atolls where because of the specialised environment, selected local talls are recommended.

In addition to the use of improved planting material the Government stresses the importance of proper nursery management and adequate selection. The recommendation to use polybag nurseries whereever practical is assisting this.

A recent development in the coconut industry is the under-planting of coconuts on suitable soils with cocoa so increasing the productivity per unit of land area. In some areas this has necessitated the thinning of existing coconut stands. However, experience has shown that even where the population of palms is thinned to $50 \%$ of its original density copra yields can be maintained in part due to the effects of fertilization and the better maintenance of the cocoa. This system is being adapted by both the plantation and smallholder sector and is expected to expand in future.

Research is also looking at intercropping coconuts with other crops with emphasis on the traditional staple root crops such as taro and sweet potato and with new crops for export particularly spices. 
In the late 1970s and early 80s the Agriculture Division in co-operation with the University of Queensland conducted an investigation into the practicalities of improved pasture production under coconuts for raising beef cattle. Results indicate that because of the conflict between adequate economic populations of coconuts and a population of palms that will allow sufficient light transmission for the establishment of improved productive pastures beef production per se under coconuts is limited. However there is a place for cattle to be used to keep the land under palms clean so facilitating the harvesting of nuts whilst at the same time producing some meat as a bonus.

With depressed commodity prices, increasing costs of production and competition from other vegetable oils and fats Solomon Islands is very aware of the need for the more economic production of copra. To this end investigations are in hand to cut down handling and collecting costs and also the costs of drying.

In 1985 an EEC funded smallholder coconut survey was carried out in the country which has produced valuable base line data on the industry which has been reported by the statistics Office SIG (1986). As a result of this survey the government is contemplating embarking on a coconut development programme for the smallholder sector.

The principal objective of the Project will be to improve the productivity of existing smallholder coconut plots. A new planting scheme is not considered appropriate or desirable as this could lead to negative implications for subsistence production.

The proposed project components include fertilizer trials on selected smallholder plots to be later used as demonstration plots; entomological research in the control of Amblypelta; assistance to the improvement of the quality of copra produced, strengthening of extension services and institutional support to marketing.

Whilst it is the policy of the Government of Solomon Islands to diversify the cash crop production in the country in the future it fully realises the importance of this crop as a staple food; a cash crop as copra and possibly as a producer of non traditional exports such as coconut timber or

coconut cream and will in future do all it can to encourage, stimulate and improve the coconut industry of Solomon Islands.

\section{ACKNOWLEDGEMENT}

The author wishes to acknowledge the permission of the Permanent Secretary, Ministry of Agriculture and Lands to publish this paper. 


\section{REFERENCES}

Agror and Hydrotechnits GMPH (1985), Coconut Development, Project Phase I, Coconut Survey.

Ele G.J. (1982), The Solomon Islands Copra Industry. A Statistical Picture. Proceedings of Solomon Islands Coconut Industry Work Shop. Ministry of Home Affairs and National Development, Honiara, Solomon Islands.

Hansel J. RF \& Wall JRD (1976), Land Resources of the Solomon Islands - Ministry of Overseas Development, London, UK.

Solomon Islands Government (1982), Annual Report the Research Department 1982. Solomon Islands Government.

Statistics Office (1 985), Sample Survey of Smallholder Coconuts, 1985 Ministry of Finance \& Ministry of Agriculture and Lands, Solomon Islands. 